\title{
ROCK GLACIERS OF THE DALTON RANGE, KLUANE RANGES, SOUTH-WEST YUKON TERRITORY, CANADA
}

\author{
By Peter G. Johnson and Diane Lacasse
}

(Department of Geography, University of Ottawa, Ottawa, Ontario K1N 6N5, Canada)

\begin{abstract}
Glaciated valleys of the Dalton Range in the south-west Yukon Territory are dominated by rock glaciers identified as glacier ice-cored debris systems. The two rock glaciers studied have different amounts of deformation at present, resulting from post-formation mechanics.

The primary formation of lobes of the rock glaciers resulted from periods of glacier activity in the Neoglacial, although older lobes, probably late Pleistocene in age, occur below the Neoglacial lobes. The hydrological systems of the rock glaciers have played a major role in the post-formation deformation of the land forms and the present drainage system is entirely sub-surface. The explanation for the extensive occurrence of rock glaciers in the Dalton Range is lithological as a result of the high susceptibility of the Upper Jurassic/Lower Cretaceous sediments to frost action and glacier erosion.
\end{abstract}

\section{INTRODUCTION}

Glacier ice-cored debris-system rock glaciers (Johnson, 1974, 1980a, 1987; Whalley, 1974) are one very distinct type of the suite of land forms known as rock glaciers. Barsch (1988) has made a very strong statement that this is an erroneous interpretation and that all rock glaciers are periglacial in origin, a position that has also been advocated by Gorbunov (1983) and Haeberli (1985). In the south-west Yukon Territory, however, most Neoglacial deposits are cored extensively by glacier ice. Continuity of glacier ice is visible from current glaciers through lateral moraines, outwash deposits, and the maximum Neoglacial position moraines, and from current glaciers through lateral moraines into rock glaciers. The rock glaciers form where the glacier surface becomes totally covered in debris. Characteristically, they occur in cirques or narrow glaciated valleys. Johnson $(1980 \mathrm{a}, \mathrm{b})$ has discussed glacier ice-cored debris-system rock-glacier formation in the St. Elias Mountains. In contrast, talus rock glaciers are not directly related to glacier activity, although they form in glaciated terrain, may be composed of glacial deposits as well as talus, and may contain some stagnant glacier ice. Land forms of this type are periglacial in origin (White, 1976, 1981; Giardino, 1983; Haeberli, 1985; Barsch, 1988). The collapse of unstable slopes has also been proposed as a possible origin for some rock glaciers (Johnson, 1984; Maxwell, unpublished).

For a long time, rock glaciers were considered to be unusual occurrences. It has become apparent that this suite of mass-movement forms is a common valley-bottom or slope formation. In the narrow valleys of the Donjek and Kluane Ranges on the eastern margin of the St. Elias Mountains of the south-west Yukon, they are a dominant element of the landscape. An example of an area dominated by the glacier ice-cored type of rock glacier is the Dalton Range, a component of the Kluane Ranges (Fig. 1).

The Dalton Range is composed of sediments and minor volcanic rocks of the Dezadeash Group of the Upper Jurassic/Lower Cretaceous (Eisbacher, 1975; Read and
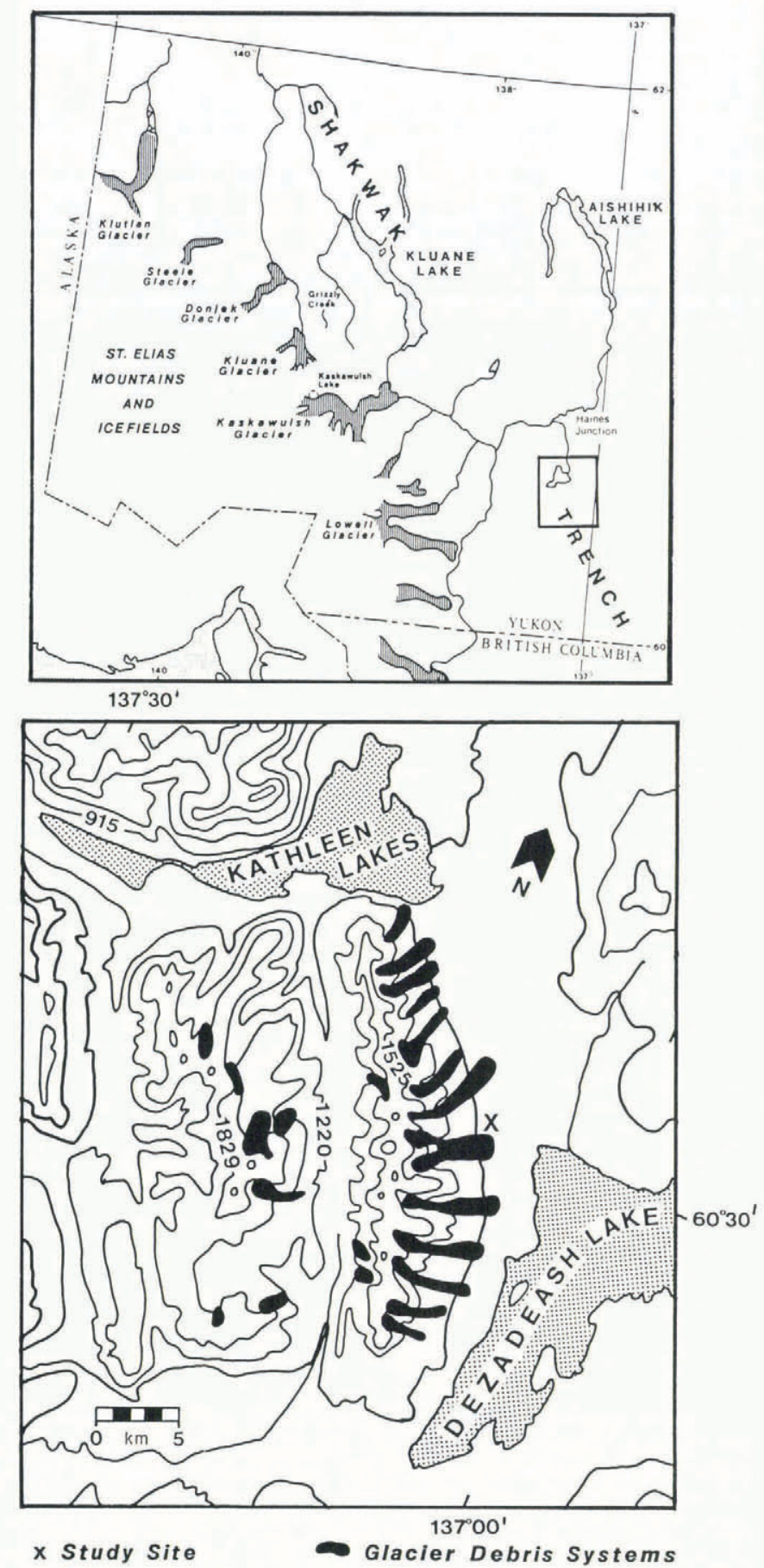

Fig. 1. Location of the glacier ice-cored rock glaciers and the study site in the Dalton Range. 
Monger, 1975). Sandstones and siltstones, complicated by slide masses and turbidites, and deformed by three major geological events (Eisbacher, 1975), occur as a highly faulted and folded zone. The rocks are very susceptible to glacier erosion and periglacial weathering. The narrow glacial valleys and the high volume of debris supply have been particularly important to the formation of the rock glaciers.

The Dalton Range consists of two north-north-west to south-south-east trending ridges rising to a maximum elevation of $2325 \mathrm{~m}$ to the east of a central valley which has a maximum elevation of $1375 \mathrm{~m}$. The higher eastern ridge is incised by a series of cirques and glacial valleys, which are most pronounced on the east-facing escarpment overlooking Dezadeash Lake. Thirteen valleys, incised $500-700 \mathrm{~m}$, terminate as hanging valleys at about the $1100 \mathrm{~m}$ level above Shakwak Trench (Figs 1 and 2), and all contain massive glacier ice-cored rock glaciers.

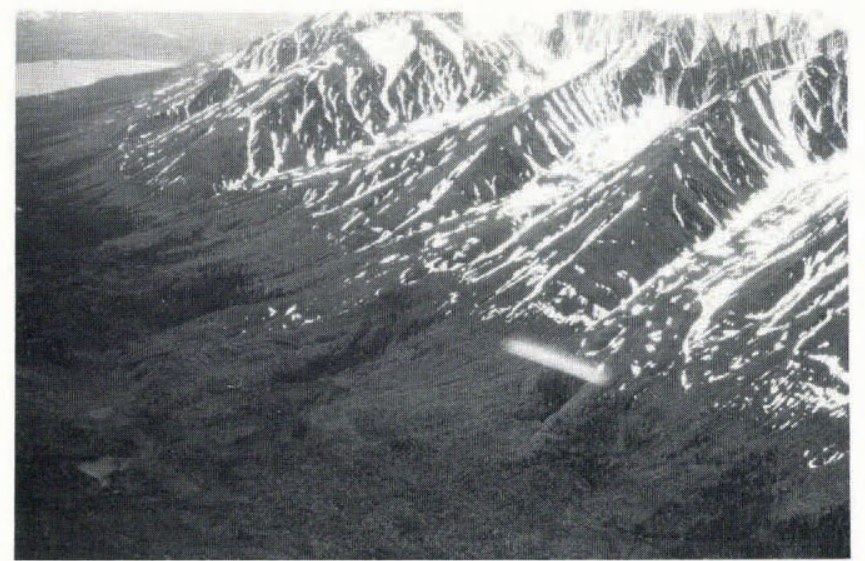

Fig. 2. The east-facing slope of the Dalton Range with glacier ice-cored rock glaciers in the cirques and the valleys. (Photograph by P.G. Johnson.)

The general pattern of the glacial history of the region was one of decreasing ice cover during successive stages of the Pleistocene with retreat of the ice from Shakwak Trench, the structural depression to the east of the Kluane Ranges, by 12500 year B.P. (Denton and Stuiver, 1966). From the late Pleistocene through the Holocene, the Dalton Range has only been affected by local glaciation. Several minor glacial episodes during the Holocene (Denton and Karlen, 1977; Kristjanson, unpublished) culminated with the Neoglacial advance. From evidence of late Holocene glaciation in various areas, the Neoglacial has been defined temporarily as dating from approximately 6000 year B.P. (Benedict, 1973; Griffey, 1976; Luckman and Osborn, 1979; Blake, 1981; Ellis and Calkin, 1984).

The mechanisms of movement, the current activity, and the history of two of the land forms were studied in 1985. Additional objectives were to determine the reasons for the prominent development of the rock glaciers in the range and the implications of these forms with regard to the evolution of the post-glacial landscape. The two rock glaciers were selected both for scientific and practical reasons. Scientifically, the forms, although apparently glacier ice-cored rock glaciers, had a number of morphological contrasts. Practically, they occurred in neighbouring and confluent valleys and were one of the few sites where a surface-water supply for a camp existed.

\section{DESCRIPTION OF THE ROCK GLACIERS}

The two rock glaciers are located in valleys which start below the highest peak in the range. The valley form is asymmetrical with very steep north-facing slopes and shallower, debris-mantled, south-facing and headwall slopes (Fig. 3). The majority of debris supply to the glacier surfaces is from the north-facing slopes. The higher parts of the valleys contain some remnant glacier ice and permanent snow patches. Morphologically, these higher parts

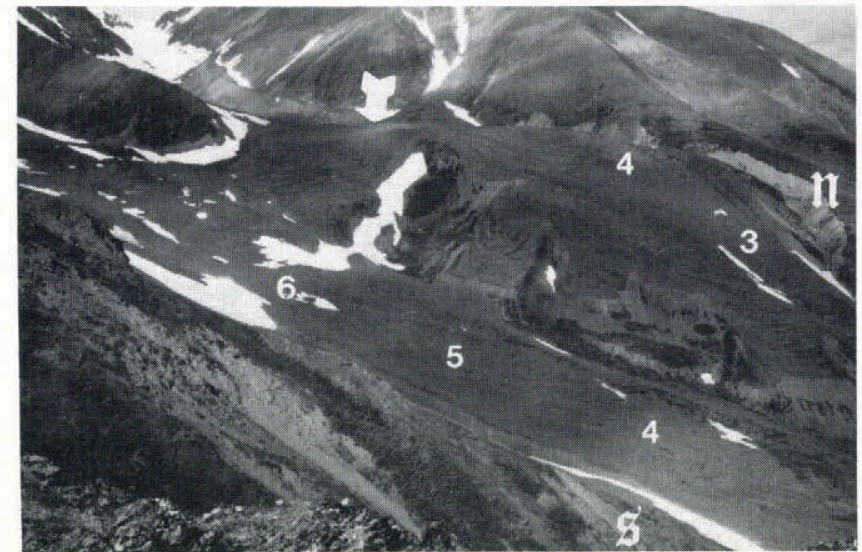

Fig. 3. The two study rock glaciers at the point of confluence of their valleys. The asymmetrical upper valley of the northern form is visible in the upper left of the photograph. Numbers and letters are referred to in the text. (Photograph by P.G. Johnson.)

of the valleys are typical glaciated valleys with lateral moraines, which are particularly prominent along the south-facing slopes, small terminal moraines, and valley-floor ice-contact land forms. Overlooking Dezadeash Lake, the valleys start to open out and the lateral moraines grade into the rock glaciers where there is a spread of debris across the valley. In the more northerly valley, the transition is marked by ice-contact deposits and a line of small sink-holes which terminate in one massive sink-hole (Fig. 4). The massive ice core of the land form was exposed at the bottom of the sink-hole. The ice contained sediment bands which dipped up-valley and were contiguous with the moraine ice, and were interpreted as being glacial in origin. In a similar form in Grizzly Creek, continuity of the ice could be observed from the glacier through the ice-cored moraines to the sink-hole where glacier discharge entered the rock glacier (Johnson, 1980a). In the more southerly valley, the transition to the rock glacier is more gradual and a central drainage channel continues down the centre of the rock glacier without any well-defined sink-hole.

On the northern form, the rock glacier down-valley of the sink-hole is composed of major flow lobes with small flow ridges $2-3 \mathrm{~m}$ in height developed in the surficial deposits. As the rock glacier extended to the break of slope of the hanging valley, a series of smaller rock glaciers formed along the terminus (Fig. 3). Longitudinal shear zones were produced along the northern lateral margin where successively younger periods of glacier movement have pushed into the central section of the rock glacier (Fig. 4).

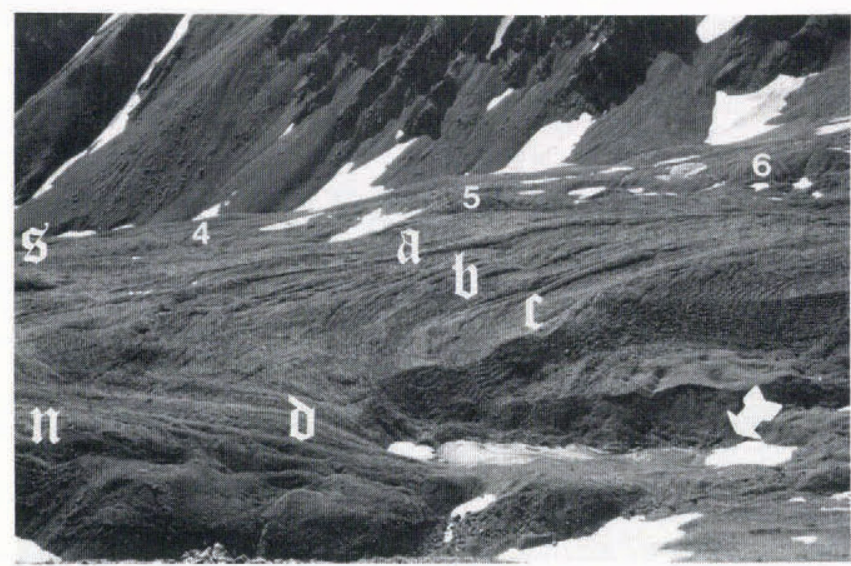

Fig. 4. The large sink-hole at the head of the northern rock glacier. The glacier ice core is in the lower right and is indicated by a broad arrow. The lateral shear zones are located in the lower left of the photograph. Numbers and letters are referred to in the text. (Photograph by P.G. Johnson.) 
TABLE I. LICHEN AND VEGETATION COVER ON THE NORTHERN ROCK GLACIER (AFTER LACASSE, UNPUBLISHED)

\begin{tabular}{|c|c|c|c|c|c|c|c|c|}
\hline Lobe & 1 & 2 & 3 & 4 & $A$ & $B$ & C & $D$ \\
\hline Lichen cover on rocks (\%) & 10.0 & & 20.0 & 30.0 & 90.0 & 5.0 & 10.0 & 80.0 \\
\hline Rhizocarpon geographicum (\%) & & & 20.0 & 20.0 & 60.0 & $<5.0$ & $<5.0$ & 55.0 \\
\hline Largest Rhizocarpon geographicum & & & 4.0 & 4.4 & 54.0 & 31.0 & 23.0 & 27.0 \\
\hline Average of 50 Rhizocarpon geographicum & & & 2.5 & 0.5 & 15.03 & 15.15 & 7.67 & 13.21 \\
\hline Vegetation cover $(\%)$ & 100.0 & 75.0 & 70.0 & 70.0 & & & & \\
\hline
\end{tabular}

Sections in these zones show boulders with voids extending to depths greater than $1.5 \mathrm{~m} .50 \mathrm{~cm}$ to either side of these zones, the deposits consist of boulders and gravels with a sand matrix. Imbrication parallel to these zones demonstrates a former occurrence of differential movement. The temporal breaks between the formation of each surface are demonstrated by progressively more mature soil profiles and vegetation communities, and increasing lichen cover and size towards the margin of the land form (Lacasse, unpublished). A summary of the lichen and vegetation data is presented in Table $I$ and the locations are indicated on Figures 3, 4, and 5 .

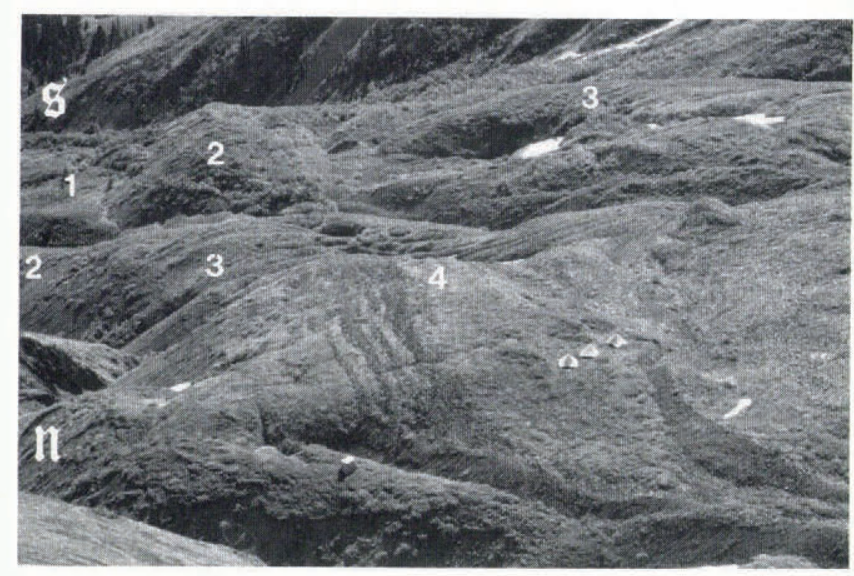

Fig. 5. The lower sections of the two rock glaciers. Numbers and letters are referred to in the text. (Photograph by P.G. Johnson.)

The southern form is composed of a series of lobes which extend the entire width of the valley. The lobes highest in the valley have no vegetation or lichen development (6 in Table II; Fig. 3) and have a dry central drainage channel which does not have any sink-holes. The central lobes (Nos 2-5 in Table II; Figs 3, 4, and 5) range from lichen-covered ( 4 and 5 ) to vegetation-covered ( 2 and 3). Lobe 2 supports an alpine/willow scrub-vegetation complex, which is disintegrating because this is the most active of the lobes at present. The central drainage channel is not prominent in lobes 3 and 4 , although lobe 3 has a channel carved by a stream resurgence (Fig. 5) (see hydrology discussion). The oldest lobe is a stable, low-relief form with a mature spruce, willow, and juniper vegetation association (Table II; after Lacasse, unpublished).

Both of the rock glaciers are composed of frost-shattered and glacially transported debris from the Dezadeash Group of rocks. The material near the surface is angular and has a wide range of particle size (sands to $1 \mathrm{~m}$ boulders). The major source of this material was valley-side rock-fall on to the glacier surface. There are no exposures of the material with depth, and lobe fronts are dominated by material off the surface of the rock glacier; thus, it is impossible to assess the contribution of glacially eroded material. The deep incision of the valleys indicates very active glacial erosion and the structure of the land forms might be a three-layered rock-fall and ablation debris, ice, basal load system with the gradual disappearance of the ice in the older lobes. Shallow excavations in the rock glaciers reveal a surface layer of $0.5-1 \mathrm{~m}$ of large boulders with voids. Below this the materials range from coarse gravels, with sand and fine gravel matrix, to sands. The frost table in mid-July was at a depth of $1.5-2 \mathrm{~m}$.

A Geonics EM16R resistivity meter was used to determine the structure of the rock glacier below the excavation depths. "The EMI6R measures the ratio and the phase angle between the horizontal electrical and magnetic fields of the wave propagated by distant VLF radio transmitters in order to determine the resistivity of the ground" (EM16R operating manual; Geonics Ltd). Resistivity values of $5000-6000 \mathrm{ohm} \mathrm{m}$ were obtained on bedrock and on $20 \mathrm{~m}$ of till, without ice lenses, over bedrock. On the higher parts of the rock glaciers, apparent resistivity values of $10000-15000 \mathrm{ohmm}$ were measured with phase angles close to $45^{\circ}$, indicating a high-resistivity layer close to the surface. This high-resistivity value is indicative of massive ice in the land form. In the lower parts of the rock glaciers, apparent resistivity values fell to as low as $5000 \mathrm{ohmm}$, indicating that there was no massive ice in these parts of the land forms. Interpolation from the exposures of glacier ice indicates that the rest of the ice core is probably glacial in origin. The survey indicated that the upper $850 \mathrm{~m}$ of the southern rock glacier and the upper $500 \mathrm{~m}$ of the northern rock glacier retain an ice core and that ice may still exist in parts of the land forms below this level. There does not appear to be an ice core in the extension rock glaciers of the northern form.

TABLE II. LICHEN AND VEGETATION COVER ON THE SOUTHERN ROCK GLACIER (AFTER LACASSE, UNPUBLISHED)

Lobe

1

23

Lichen cover on rocks (\%)

Rhizocarpon geographicum (\%)

Largest Rhizocarpon geographicum 
TABLE III. LIST OF THE MAJOR VEGETATION SPECIES ON THE LOBES OF THE SOUTHERN ROCK GLACIER

Lobe 1

Draba caesia, Empetrum nigrum, Epilobium angustifolium, Festuca altaica, Juniperus communis, Lupinus arcticus, Myosotis alpestris, Picea sp.. Ribes oxyacanthoides, Rosa acicularis, Salix glauca, Vaccinium vitisidaea, Zygadenus elegans

\section{Lobe 2}

Epilobium angustifolium, Epilobium latifolium, Lupinus arcticus, Mertensia paniculata, Poa arctica, Rosa woodsii, Salix polaris, Saxifraga tricuspidata, Solidago multiradiata

Lobe 3

Antennaria pulcherrima, Catilleja sp., Chamaedaphne calyculata, Epilobium angustifolium, Festuca altaica, Juniperus communis, Lupinus arcticus, Mertensia paniculata, Picea sp., Potentilla diversifolia, Salix polaris, Salix reticulata, Saxifraga tricuspidata, Solidago multiradiata, Stellaria longipes

Lobe 4

Artemisia alaskana, Epilobium latofolium, Lupinus arcticus, Oxytropis sp., Salix arctica, Saxifraga tricuspidata, Trisetum spicatum

\section{HYDROLOGICAL SYSTEMS OF THE ROCK GLACIERS}

The present hydrological systems of the rock glaciers are almost entirely sub-surface. Abandoned stream channels are evidence of greater importance of surface drainage in the past. They are both indicative of the importance of the hydrological system in the formation of this land form. At present, surface streams only occur for short distances below snow-packs and below residual glacier ice in the upper valleys. The existence of sub-surface drainage streams was indicated by the sound of flowing water detected through the overburden. Although the drainage is essentially sub-surface and in distinct stream courses in the upper parts of the land forms, no stream resurgences were found at the termini of the rock glaciers. This prevented quantitative assessment of the hydrological system.

The northern rock-glacier valley has a sub-surface stream that flows through the ice-contact deposits above the main sink-hole. This drainage formerly entered the rock glacier at the sink-hole. The sink-hole was progressively enlarged by the action of the stream and the melt of exposed areas of the ice core. The sediments deposited in the sink-hole (Fig. 6) indicated that the stream channel had been blocked, causing the accumulation of $2.73 \mathrm{~m}$ of fluvial deposits. The sequence shows a number of rapid fluctuations from low- to high-energy conditions. In 1985, the drainage was in an ice-walled channel at the up-valley end of the sink-hole where a small debris flow had exposed the ice core and a short tunnel to the stream course (Fig. 4, position X). A section in the southern wall of the sink-hole, where the surface was pitted with small kettleholes, had ice covered by till, $0.4-0.5 \mathrm{~m}$ of fluvially bedded sands and gravels, and three beds of $0.8-1 \mathrm{~m}$ thick heterogeneous gravels with lenses of bedded sands and silts. There was, therefore, fluvial activity during rock-glacier formation at a height of $7-8 \mathrm{~m}$ above the present elevation of the sink-hole floor. This fluvial activity would be from an early glacial phase in the rock-glacier formation.

The interpretation of the bedded sands and gravels in the kettle-hole section and the sink-hole section is difficult. The rapid changes between energy conditions indicated in these sections might represent differences in annual regimes of the glacier-discharge stream. Research on contemporary glacier discharge and suspended-sediment regimes demonstrates that rapid changes in sediment transport can also occur within one season (research in progress). These sections might represent a number of years of accumulation or might even be very rapid sedimentation in the last phase of stream blockage. No temporal information on the formation of the rock glacier could be gained.

\section{SINKHOLE SECTION}

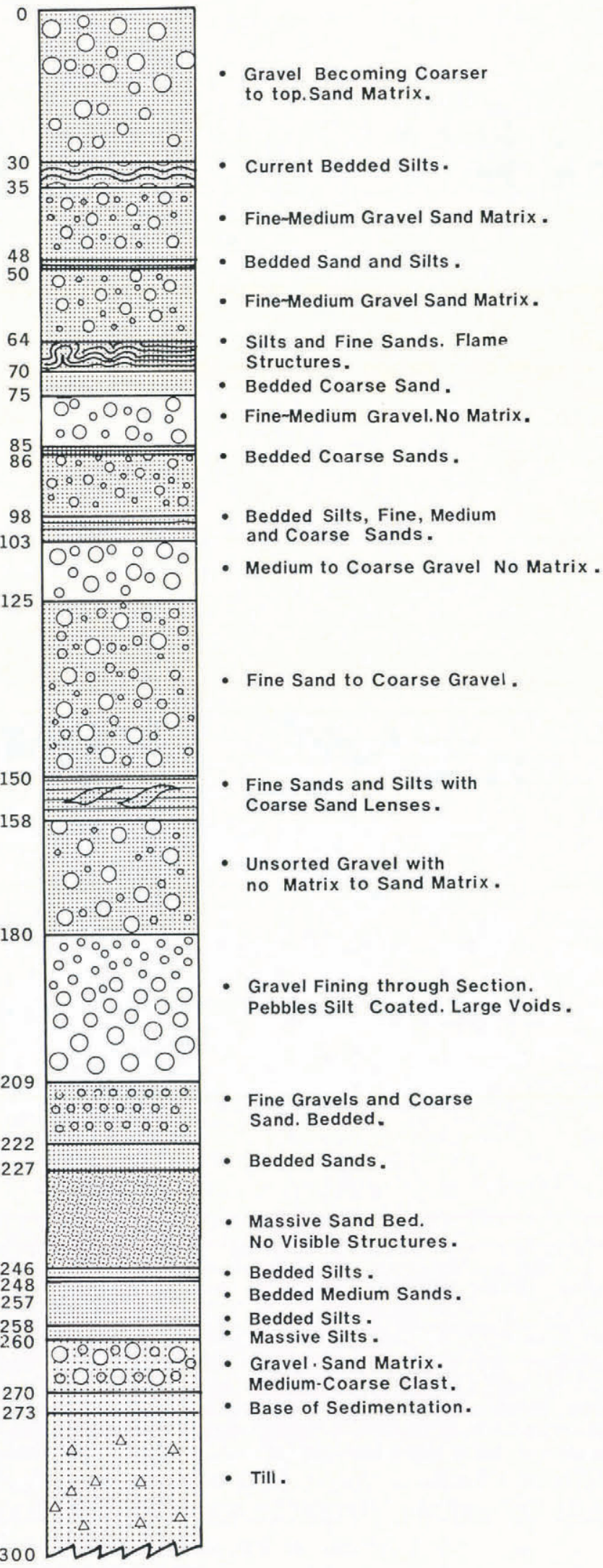

Fig. 6. The stratigraphy of the deposits in the large sink-hole.

There is also a central drainage channel on the lowest lobes of this northern rock glacier. The channel starts at the base of the steepest slope off the main section of the rock glacier (Fig. 3) and terminates in a number of small sink-holes. The channel was probably formed by resurgence of drainage through the rock glacier, and this sapped the base of the slope causing the instability of the rock-glacier surface above. 
No resurgence of water was found around the terminus of this land form. The only evidence of hydrological activity at the terminus is found in the unstable frontal slopes. Here, water seepage occurs along planar surfaces and provides a water supply to a line of vegetation which has developed on the slopes (Fig. 3, indicated by arrows). Sections dug into the terminus slopes indicated that this was a permafrost surface. Although the sections were cut into apparently active unstable $40-60^{\circ}$ slopes, the vegetation development suggests that this is a relatively stable condition. Active slope movement would not have allowed the trees to become established, and an agrading or degrading permafrost surface would result in movement of the water supply and changes in the vegetation. At the permafrost table, the composition of the rock glacier was sands to coarse gravels with a low interstitial ice content.

In the southern valley, snow and ice melt percolates into the glacial deposits above the main part of the rock glacier. The central drainage channel indicates some surface drainage during formation of lobes 4,5 , and 6 (Fig. 3). Lobe 4 (Fig. 3) was a sink-hole and lobe 3 (Fig. 5) has a large resurgence pit. The latter is a large conical pit in the centre of the lobe with a water-eroded channel extending out through the north-east part of the lobe terminus to an alluvial fan. The fan covers part of the surface of the older lobe 2. The resurgence pit is about $10 \mathrm{~m}$ deep (the winter snow had not melted out by the end of July) and must have been produced by a large water flow. No stream resurgences were found along the terminus of lobe 1 .

Lobe 2 is the only one which has any indication of active flow (Fig. 5). The terminus slope is up to $50^{\circ}$ and material from the surface is sliding down-slope on to the surface of lobe 1 , where it is being over-ridden by the lobe advance.

\section{DISCUSSION}

Most Neoglacial glaciated areas in the St. Elias Mountains have extensive ice cores. The glacier ice core is exposed through the recent recessional moraines and outwash to the large Neoglacial lateral and terminal moraines in Grizzly Creek, in Donjek Valley, and at the Kaskawulsh Glacier research sites. In the Kaskawulsh basin, extensive glacier-ice cores exist in kame-and-kettle topography at the Kaskawulsh Lake site, and extensive stagnant ice tongues covered by thin debris covers occur in Steele Valley, Spring Valley, and in the Kaskawulsh basin. Continuity of glacier ice has been observed from a cirque glacier, through massive ice-cored moraines and into the upper zones of a rock glacier in Grizzly Creek. There is no doubt that massive glacier-ice cores exist in all depositional environments dating from the Neoglacial period. The main mass of each of the Dalton Range rock glaciers is glacier-ice cored and the primary movement of the land forms is the result of the deformation of the ice. Deformation of one long tongue of debris-covered ice will not produce the sequence of major lobes found on the rock glaciers. Frequently, these long tongues stagnate in situ and produce stagnant ice/karst-type landscapes (Clayton, 1964; McKenzie and Goodwin, 1987).

The Neoglacial period has been one of a number of glacier fluctuations (Burrows and Gellatly, 1982) producing multi-ridged ice-cored moraines (Denton and Stuiver, 1966). The same pattern of glacier fluctuation occurring where extensive debris covers have formed on glacier surfaces will produce a number of glacier ice-cored lobes. Each of the main lobes of the rock glacier is produced during a period of glacial activity (Fig. 7). Terminal moraines and the lobes of the rock glaciers preserve the same record of glacier activity. The number of periods of glacier activity in the Neoglacial, indicated by the moraines and rock-glacier lobes, and slow vegetation colonization and lichen growth, would account for the sometimes contradictory evidence on relative age of surfaces.

Although periods of glacier activity are responsible for the main lobe formation, other deformation processes can modify the land forms. First, the ice core can continue to deform under gravitational stress and surface loading. Secondly, ice advance into the stagnant core of an older lobe increases stress in the stagnant ice and leads to

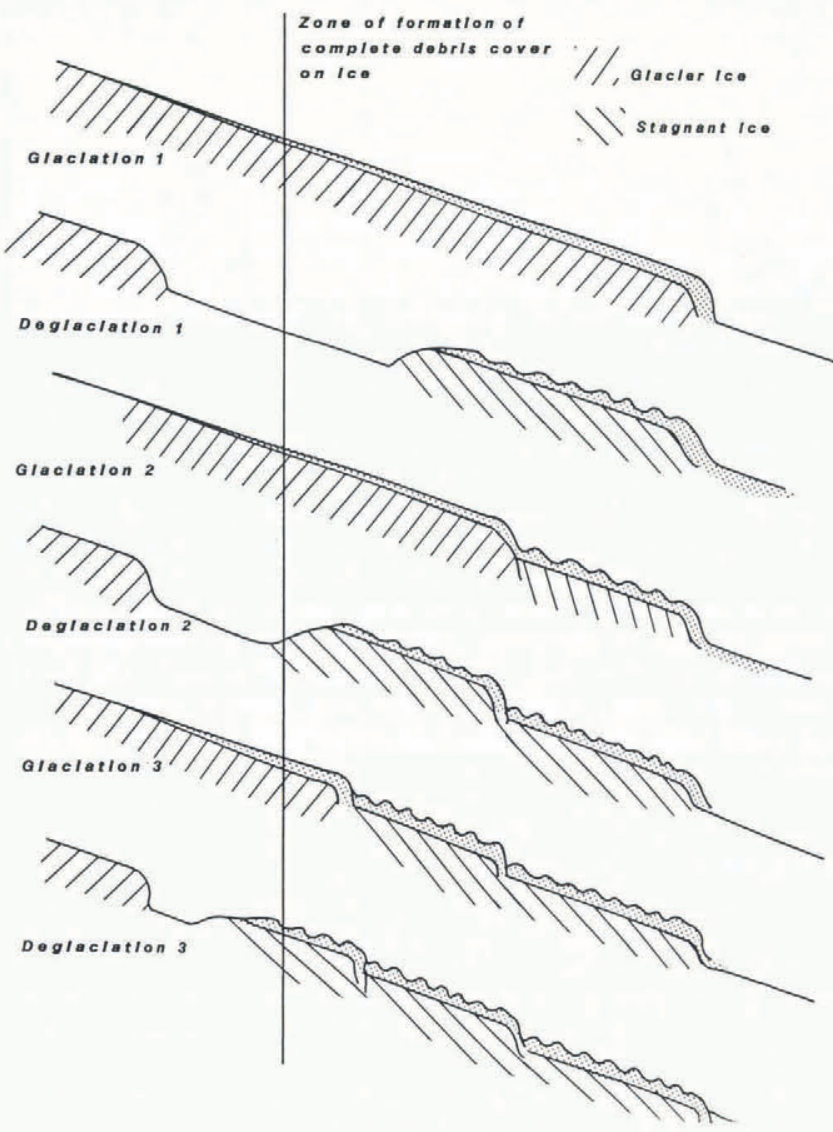

Fig. 7. Schematic of the formation of glacier ice-cored rock glaciers by periods of glacier advance.

increased rates of deformation. Thirdly, hydrostatic conditions in the lobes caused by snow and ice melt in the upper valley may cause local movement. Fourthly, the surface deposits may develop creep flow as a result of interstitial ice content or differential movement along the ice/deposit interface. All of these mechanisms contribute to the formation of multiple minor flow ridges on the rock-glacier surface.

Movement rates can be the result of primary or secondary movement processes. On the northern rock glacier there have been a number of small extension flows of parts of the terminus of the main rock glacier (Fig. 3). Sections along the margins of these indicate surface flow with over-riding of solifluction lobes. Although these forms have steep terminus slopes of $>45^{\circ}$, there is little forward movement of the mass of the rock glacier at present. Trees developed along the seepage lines are only slightly deformed at the base of the trunk and there is no evidence of active rock-glacier advance over the pro-glacial surface. On the southern rock glacier, the only active lobe is lobe 2 which is advancing over lobe 1 , the oldest of the lobes. The surface of lobe 2 has been stable recently because a mature soil profile had developed on the lobe with a scrub-vegetation complex. The soil and vegetation are being destroyed by the current activity. The cause of the re-advance was not apparent but it may be related to the changing hydrological conditions as the ice core degrades, because the resurgence pit and alluvial fan on lobe 3 above indicate considerable hydrological activity. The only evidence for the absolute age of the rock glaciers is a modern date from lobe 3. The date was obtained from a piece of wood lying on the rock surface at the base of the soil and it is questionable whether this is a good indicator. It is hypothesized that most of the lobes $(2-6)$ date from the Neoglacial and recent periods, and that lobe 1 is much older. The Neoglacial lobes correspond to the periods of ice activity indicated in the moraines of Kaskawulsh, Donjek, and Grizzly Glaciers. 
The debris supply to the glacier surface is critical to the formation of these rock glaciers. Johnson (1980b) proposed a simple model relating valley morphology and debris supply to their formation because of the highly erodable nature of the Dezadeash Group of rocks which allowed deep glacial incision and high volumes of supply by periglacial weathering from the valley sides. Additional lobes might be added to these rock glaciers if the glaciers re-advance in the future. Older Holocene surfaces may have been over-ridden or truncated by the Neoglacial re-advance of the glaciers.

The fact that these land forms are ice-cored suggests that the final morphological expression upon total deglaciation will depend on the relative volumes of rock and ice, and on the processes of melt of the ice. Ice-cored moraines in the St. Elias Mountains rarely have more than $2 \mathrm{~m}$ of till over the ice and the resistivity survey of the rock glacier indicates a thin layer of rock debris. Degradation of the land form will occur by down-wasting of the ice as a result of heat flow through the deposits, collapse into ice-walled drainage channels through the land forms, and rapid melt of the ice when exposed by melt-water activity or slump and mud-flow processes on the surface.

\section{SUMMARY}

The Dalton Range rock glaciers are primarily glacier ice-cored debris-system forms and most of the lobes date from the Neoglacial period. Older remnants could not be dated but it is thought that they were probably late Pleistocene to early Holocene after the end of regional glaciation. Any early to middle Holocene components of the land forms would have been destroyed or altered by the Neoglacial advances. This pattern of Holocene advances, followed by more extensive Neoglacial advances, has been suggested by Denton and Karlen (1973). The lithology of the Dezadeash Group makes the Dalton Range particularly suitable for the formation of glacier ice-cored rock glaciers, and the valleys of the range, therefore, contain a unique record of recent glacier fluctuations.

\section{ACKNOWLEDGEMENTS}

The authors wish to acknowledge the financial support of the Natural Sciences and Engineering Council of Canada (operating and northern supplement grants to P.G.J.) and the Northern Science Training Grants Programme of the Department of Indian and Northern Affairs Canada (grant to D.L.). They also wish to acknowledge the logistic support of the Arctic Institute of North America at its Kluane Lake Research Station, and the field assistance of Ms J.N. Kasper, Ms C. Chinkiwsky, Ms F. Jensen, and $\mathrm{Mr}$ J. Marcellus.

\section{REFERENCES}

Barsch, D. 1988. Rockglaciers. In Clark, M.J., ed. Advances in periglacial geomorphology. Chichester, etc., John Wiley and Sons, 69-90.

Benedict, J.B. 1973. Chronology of cirque glaciation, the Colorado Front Range. Quat. Res., 3(4), 584-599.

Blake, W., jr. 1981. Neoglacial fluctuations of glaciers, south-eastern Ellesmere Island, Canadian Arctic archipelago. Geogr. Ann., 63A(3-4), 201-218.

Burrows, C.J. and A.F. Gellatly. 1982. Holocene glacier activity in New Zealand. Striae, 18, 41-47.

Clayton, L. 1964. Karst topography on stagnant glaciers. $J$. Glaciol., 5(37), 107-112.

Denton, G.H. and W. Karlén. 1973. Holocene climatic variations - their pattern and possible cause. Quat. Res.,
3(2), 155-205

Denton, G.H. and W. Karlén. 1977. Holocene glacial and tree-line variations in the White River Valley and Skolai Pass, Alaska and Yukon Territory. Quat. Res., 7(1), 63-111.

Denton, G.H. and M. Stuiver. 1966. Neoglacial chronology, northeastern St. Elias Mountains, Canada. Am. J. Sci., 264, 577-599.

Eisbacher, G.H. 1975. Operation Saint Elias, Yukon Territory: Dezadeash Group and Amphitheatre Formation. Geol. Surv. Can. Pap. 75-1, Pt. A, 61-62.

Ellis, J.M. and P.E. Calkin. 1984. Chronology of Holocene glaciation, central Brooks Range, Alaska. Geol. Soc. Am. Bull., 95, 897-912.

Giardino, J.R. 1983. Movement of ice-cemented rock glaciers by hydrostatic pressure: an example from $\mathrm{Mt}$. Mestas, Colorado. Z. Geomorphol., 27(3), 297-310.

Gorbunov, A.P. 1983. Rock glaciers of the mountains of middle Asia. Permafrost. Fourth International Conference. Proceedings. July 17-22, 1983. Washington, DC, National Academy Press, 359-362.

Griffey, N.J. 1976. Stratigraphical evidence for an early neoglacial glacier maximum of Steikvassbreen, Okstindan, north Norway. Norsk Geol. Tidsskr., 56(2), 187-194.

Haeberli, W. 1985. Creep of mountain permafrost: internal structure and flow of Alpine rock glaciers. Eidg. Tech. Hochschule, Zürich. Versuchsanst. Wasserbau, Hydrol. Glaziol. Mitt. 77.

Johnson, P.G. 1974. Mass movement of ablation complexes and their relationship to rock glaciers. Geogr. Ann., 56A(1-2), 93-101.

Johnson, P.G. 1980a. Glacier-rock glacier transition in the southwest Yukon Territory, Canada. Arct. Alp. Res., 12(2), 195-204.

Johnson, P.G. 1980b. Rock glaciers: glacial and non-glacial origins. International Association of Hydrological Sciences Publication 126 (Workshop at Riederalp 1978 - World Glacier Inventory), 285-293.

Johnson, P.G. 1984. Paraglacial conditions of instability and mass movement; a discussion. $Z$. Geomorphol., 28(2), 235-250.

Johnson, P.G. 1987. Rock glacier: glacier debris systems or high-magnitude low-frequency flows. In Giardino, J.R., J.F. Schroder, jr, and J.D. Vitek, eds. Rock glaciers. Boston, MA, Allen and Unwin, 175-192.

Kristjansson, F.J. Unpublished. Cirque multiple glaciation, Grizzly Creek, Yukon Territory, and palaeoclimatic implications. (M.A. thesis, University of Ottawa, 1980.)

Lacasse, D. Unpublished. Glaciation locale pendant le Pleistocène Supérieur et l'Holocène dans les chaînes Ruby et Dalton, sud-ouest du Territoire du Yukon. (M.A. thesis, University of Ottawa, 1987.)

Luckman, B.H. and C. Osborn. 1979. Holocene glacier fluctuations in the middle Canadian Rocky Mountains, Quat. Res., 11(1), 52-77.

McKenzie, G.D. and R.G. Goodwin. 1987. Development of collapsed glacial topography in the Adams Inlet area, Alaska, U.S.A. J. Glaciol., 33(113), 55-59.

Maxwell, M. Unpublished. The role of catastrophic processes in the evolution of talus derived rock glaciers. (M.A. thesis, University of Ottawa, 1979.)

Read, P.B. and J.W.H. Monger. 1975. Operation Saint Elias, Yukon Territory: the Mush Lake Group and Permo-Triassic rocks in the Kluane Ranges. Geol. Surv. Can. Pap. 75-1, Pt. A, 55-59.

Whalley, W.B. 1974. Rock glaciers and their formation as part of a glacier debris-transport system. Reading, University of Reading. Department of Geography. (Geographical Papers 24.)

White, S.E. 1976. Rock glaciers and block fields; review and new data. Quat. Res., 6(1), 77-97.

White, S.E. 1981. Alpine mass movement forms (noncatastrophic): classification, description, and significance. Arct. Alp. Res., 13(2), 127-137. 